\title{
COMPETITION IN HEALTH INSURANCE MARKETS
}

\author{
MARK V. PaUlY* \\ I \\ INTRODUCTION
}

This article will investigate the strength of competition in health insurance markets. The focus will be on traditional economic notions of structure and performance indicators that fit the neoclassical paradigm of perfect competition. The article will also consider the form of rivalry between health insurers in less than perfectly competitive markets. The objective of the paper is to describe ways of thinking about competition in any given health insurance market and to summarize the views of those who have investigated such matters.

The broad question the article addresses is the possible sources of market power in health insurance markets. Without a source of market power, price cannot be raised above the competitive level, and antitrust issues will not arise. By cataloging the valuable services embodied in health insurance, this article will show that the "pure" insurance function-the pooling of risk for the benefit of risk-averse consumers-is unlikely to be a subject or a source of market power. The other service that health insurers provide is then investigated. This service might be defined as "cost containment," "expenditure control," or "limitation of moral hazard." In the broadest sense, it consists of the specification of the conditions under which medical services are purchased wholly or in part with insurance proceeds. The article will then examine in more detail whether in fact the markets for "pure" insurance and for cost containment have deviated from the competitive ideal. In addition, it will be shown that the ability of any insurer (even a Blue Cross or Blue Shield insurer) to obtain or retain market power in the risk-pooling function is very limited. Obtaining market power requires government action, such as especially favorable tax treatment, and is limited to whatever advantage that action conveys. The most probable source of market power for the Blue Cross and Blue Shield plans is the monopsony power which arises from their large buyer market share in the medical services market. This article will demonstrate that the market power allegedly possessed by Blue Cross and Blue Shield plans over the years must be associated with this function. Finally, the role of advertising and good will in generating market power will be examined.

Copyright $\odot 1989$ by Law and Contemporary Problems

* Professor, Leonard Davis Institute, Wharton School, University of Pennsylvania. 


\section{How to Think About Health Insurance}

This section establishes some important preliminaries. First, it will be established that the identity of the health insurance customer involves some surprising ambiguities. Next, appropriate models for the relationships between customers, health insurers, sellers of medical services, and providers of inputs to those services will be examined. The market will be shown to be complicated by a variety of transactions and a variety of product characteristics.

More than 90 percent of private health insurance in the United States is group insurance provided in connection with employment, and it therefore seems sensible to focus primarily on the extent of competition in that market. ${ }^{1}$ The most obvious way to think of the demand side of the employment group insurance market is to imagine that the employer (or, in some circumstances, the union) is the demander. Even in those firms where employees have no choice among plans, an ambiguity immediately arises-what is the demander's objective in choosing the firm from which health insurance is purchased? It is clearly not just minimum premium cost to the employer, since that objective could better be served by offering no fringe benefit at all. Because employerprovided coverage has tax advantages, ${ }^{2}$ even when cash wages are reduced by an equivalent amount, low-cost and low-benefit health insurance must eventually be less attractive than more costly but more generous coverage. Here, the assumption is that the employer chooses on behalf of the marginal employee-selecting the single insurer that employees would prefer when there is no choice, and selecting the options to be made available to employees when choices are offered.

It would be simple to imagine that the employer, personified by the benefits manager, would make the choice of type of policy, level of coverage, and identity of seller with good (if not perfect) information, since gathering such information and making such choices is the responsibility of the benefits manager. The only problem with this assumption is that if employees mistakenly prefer one insurer over another, the employer who wishes to attract those employees had better mimic their mistaken choice. The choice of an inconvenient or incompetent insurer will soon be noticed by employees, but the selection of an insurer who simply makes miserable that small fraction of employees unlucky enough to be seriously ill will not necessarily be

1. See generally Arnett \& Trapnell, Private Health Insurance: New Measures of a Complex and Changing Industry, 6 Health Care Financing Rev. 31 (1984).

2. The tax advantage arises because premium payments are a tax-deductible cost for the employer, while benefit payments are not treated as taxable income for the employee. A group of employees currently paying for their own health insurance could agree with their employer to have their money income reduced by the amount of the premium, in return for which the employer would "provide" health insurance. The result of this transaction, which gives exactly the same insurance benefits to the employees, is that each employee would reduce his income taxes by the tax that would have been paid on the income used to pay the insurance premium. See Phelps, Tax Policy, Health Insurance, and Heallh Care, in Market Reforms in Health Care 198 (J. Meyer ed. 1983). 
avoided, even by the most knowledgeable benefits manager. In any event, the analysis that follows will usually treat the choice of insurer as if it were made by a well-informed consumer, but with the occasional possibility that the choice will depend on an employee's strongly held prejudices and erroneous beliefs.

A small minority of people buy individual private insurance. In this case, there are no important tax advantages, ${ }^{3}$ and the administrative cost of insurance sold on a person-by-person basis is substantially greater than for group insurance. In both the individual and small group cases, insurers typically engage in underwriting, examining carefully the characteristics of the individual or group that affect the risk of losses, and charging higher premiums or declining to sell coverage if the risk is thought to be high. Underwriting is nonexistent for other group insurance. ${ }^{4}$

The higher administrative costs for individual insurance arise from the higher per-insured cost of selling and collecting premiums for individual or small-group buyers and from the expenses of underwriting. Consumer information is not as complete for individual insurance. With the exception of special attention to consumer ignorance, the analysis of the market for individual insurance largely parallels that for group insurance.

This describes the buyers of health insurance, but what are they buying? They are buying two things. The first is the traditional risk-spreading function of insurance. It will be argued that competition, despite possible buyer ignorance, works reasonably well for this function. The second may be broadly defined as the arrangement of some or all of the conditions of purchase of health care services. The peculiar nature of medical care makes provision of this service important for health insurance, more so than for other forms of insurance, but also leads to some fundamental peculiarities in this market not shared by other forms of insurance (or other types of services).

The main peculiarity in medical care and medical insurance markets is, of course, moral hazard. Moral hazard refers to incentive effects that insurance coverage may have on the level of medical spending. ${ }^{5}$ Current forms of

3. Private health insurance premiums can be itemized as a deduction for the individual federal income tax, but only if uninsured medical expenses exceed $7.5 \%$ of adjusted gross income. See 26 U.S.C. $\$ 213$ (1983).

4. Office of Technolocy assessment, Medical Testing and Health Insurance 5 (1988).

5. Pauly, The Economics of Moral Hazard: Comment, 58 Am. Econ. Rev. 531, 535 (1968). More precisely, insurance coverage has two kinds of effects on use. By increasing wealth in situations in which high medical expenses are incurred (and reducing wealth when expenses are low, because a premium must be paid), insurance may cause a positive "wealth effect" on use. This will occur if higher levels of wealth stimulate spending, and if this wealth effect in the high expenditure situation offsets the depressing effect of lower disposable wealth in the low expenditure state. Any insurance potentially has such a wealth effect; this effect would not be regarded as arising from a distortion in incentives, and does not cause inefficiency. See De Meza, Health Insurance and the Demand for Mediral Care, $2 \mathrm{~J}$. Health Econ. 47 (1983). But medical insurance also has a user price effect. This incentive effect is regarded as a distortion, since the effect of insurance is to make expensive medical care appear to be cheap to the user, and therefore to stimulate the potential use of care whose value to the patient is less than its cost. 
health insurance do more than transfer wealth from lucky (well) states to unlucky (sick) states; they also affect the quantity, quality, and price of the services the buyer of medical care will select. Intentionally or not, any health insurer that offers something other than "classical indemnity" coverage will affect the medical care choices of its insureds. ${ }^{6}$ The reason is that conventional insurance typically reduces the user price-the price paid out of pocket when one uses additional care-and this lower price causes the quantity of services demanded to increase. ${ }^{7}$ At a minimum, the insurer will have to take these effects into account in setting premiums. But because most of these induced changes are really the result of distorted incentives to medical care buyers, the insurer will be sorely tempted to try to exercise some direct control over medical prices, quantity, quality, and rate of technical change. Some of the most exciting innovations in health insurance represent imaginative ways to exercise this control. ${ }^{8}$ The upshot is that health insurers compete on more than just price; they compete on the basis of the methods they choose for cost control in the medical services market. This fact inextricably links health insurance markets and medical services markets; for all practical purposes risk spreading and cost control are joint products of a health insurer, with some variation in proportions possible (just as a rancher can breed for meat or hides), but with complete separation impossible. This article will take a "variable joint product" perspective on health insurance. The important thing to note is that the reason why the insurer finds it advantageous to interfere in transactions with providers springs largely from the distorted incentives offered by insurance.

This joint product nature of insurance and services gives rise to a paradox, a Catch 22, which bedevils attempts to understand competition in both health insurance and medical services. The insurer can affect the physical quantity of medical services by means of the extent of coverage, although even here the desire of physicians to adopt standard operating procedures in treating patients may limit the scope of adjustment for any single insurer. But if the insurer hopes to affect the quality or price, it will frequently have to change the decisions about those variables that producers of services would otherwise make. Viewed as a single competitive buyer, the insurer in a theoretically competitive market would not usually be given the power to affect price or average quality. That is, in competition buyers are always "price takers." The perfectly competitive insurer probably cannot affect the range of quality offerings either, at least not directly. And any impact on the quantity of

6. Here I am distinguishing between "classical indemnity insurance," which pays a fixed dollar amount conditional on the occurrence of an event over which the insured has no control whatever, and the "indemnity function of health insurance," which is the payment by insurance of medical bills, but for which consumers may have some choice as to the level of care used, and the level of bills incurred.

7. See supra note 5.

8. These innovations include Health Maintenance Organizations ("HMO's"), Preferred Provider Organizations ("PPO's"), and various types of utilization management devices used by conventional insurers. Such devices will be discussed in more detail below. See infra text accompanying note 68 . 
services used must come from the price incentive embodied in less than complete coverage-deductibles and copayments-which at least in part contradict the risk-spreading purpose of insurance. Therefore, this article argues that effective competition in the health insurance market-where "effective" means "effective in controlling cost"-negates competitive arm'slength relationships in the medical services market. Whether the alternative relationship should be called one of "market power" remains to be seen, but one can be sure that it will be something different from textbook perfect competition.

\section{III}

\section{Market Shares in Health Insurance: Facts and Theory}

The most traditional indicator of market power is the market share possessed by a dominant seller. However, as Landes and Posner have reminded us, a large market share is only necessary for market power, not sufficient.9 The meaning of "market power" used in this article is the definition suggested by Landes and Posner: the ability to maintain price profitably above the competitive level for an extended period of time. 10 The reason why market share alone is an insufficient indicator of market power is, according to Landes and Posner, because easy entry into an industry or the availability of products that are close substitutes may severely constrain any firm's ability, regardless of its current market share, to set a price different from the competitive level that increases its profits." More precisely, even a firm with a large share may find that such potential competition limits its ability to earn higher profits by setting output prices above the competitive level. Should it raise prices, its large share will evaporate. And yet the long term ability to earn above-competitive profits by raising prices is the definition of seller market power.

\section{A. Blue Cross/Blue Shield Market Shares}

The Blue plan typically has the largest market share in any local market, and Blue plans usually limit their activity to particular geographic areas (ordinarily a state or part of a state). ${ }^{12}$ The Blue plans' market shares therefore vary across the areas in which they operate. The nationwide average market share of Blue Cross/Blue Shield plans is shown in Table $1 .^{13}$

As indicated in Table 1, the share was approximately 35 percent as of 1983 and had eroded somewhat over the previous eight years, but the share was

9. Landes \& Posner, Market Power in Antitrust Cases, 94 Harv. L. Rev. 937, 947 (1981).

10. Since this article will be a discussion of buyer as well as seller market power, a more precise definition would substitute "the ability to profitably set price which deviates from the competitive level."

11. See Landes \& Posner, supra note 9.

12. However, a few of the Blue plans do compete head-to-head in part of the area in which they operate.

13. Self-insured plans administered by commercial insurers or by Blue Cross/Blue Shield are included as part of the Blue Cross/Blue Shield market share. 
TABLE 1

Private Health Insurance Benefits Market Share, by type of INSURER WHO ADMINISTERS, $1983^{*}$

$\begin{array}{ccccc}\text { Blue Cross/ } & \text { Insurance } & & \begin{array}{c}\text { Self-Administered } \\ \text { and Non-Insurer } \\ \text { Third Party } \\ \text { Administrator }\end{array} \\ 1965 & 45 & 48 & \text { HMO } & 5 \\ 1975 & 46 & 45 & 2 & 6 \\ 1980 & 38 & 46 & 4 & 10 \\ 1981 & 37 & 47 & 6 & 11 \\ 1982 & 35 & 48 & 6 & 11 \\ 1983 & 35 & 48 & 6 & 6\end{array}$

"Measured by the percentage of premiums based on the identity of the insurer who administers the plan.

Source: Arnett \& Trapnell, Private Health Insurance: New Measures of a Complex and Changing Industry, 6 Health Care. Fin. Rev. 31, 34 (1984).

still sizeable. In several states, as Table 2 indicates, the share is greater than 50 percent. The reason for the erosion appears in large part to be a shift to self-insurance. ${ }^{14}$ The main point to be made, however, is that the level of market share represented here would, by most rule-of-thumb calculations, raise concern about market power. ${ }^{15}$ The courts have, however, been reluctant to apply this mechanical reasoning to insurance markets. ${ }^{16}$ In the appellate court decision in Kartell, the court excused large market shares by pointing directly to the alleged public interest in lowering health care costs and in slowing medical care cost growth. ${ }^{17}$

An important question is the cause of such a high market share for the Blues. Identification of causation is necessary to predict consequences. If one knows the cause of this large market share, one may be able to infer whether that cause would also be expected to lead to market power.

Insight into the question of causation may come from an examination of the geographical variation in the market shares of the Blue plans. That variation is considerable, as Table 2 indicates, and has also varied over time. In some markets, the Blue share falls below 25 percent, which at least offers evidence that access to the trade name alone is not sufficient to yield substantial market share. ${ }^{18}$ But in other markets, the share is over 60 percent

14. Arnett \& Trapnell, supra note 1, at 34 show, in a table, that the Blue Cross and Blue Shield share declined as the self- insured, self-administered, and "administrative services only" shares rose.

15. For a discussion of the relationship of market share to legal definitions of monopoly, see Miller, Vertical Restraints and Powerful Health Insurers: Exclusionary Conduct Masquerading as Managed Care, Law \& Contemp. Probs., Spring 1988, at 195.

16. Kartell v. Blue Shield of Mass., 749 F.2d 922 (1st Cir. 1984), cert. denied, 741 U.S. 1029 (1985); Ball Memorial Hosp., Inc. v. Mutual Hosp. Ins., Inc., 603 F. Supp. 1077 (S.D. Ind. 1985).

17. For a discussion of Kartell, see Miller, supra note 15, at 195, 220-24.

18. Frech, Monopoly in Health Insurance: The Economics of Kartell v. Blue Shield of Massachusetts, in Health Care in America 293, 303 (H. Frech ed. 1988). 
and surprisingly stable in the face of the surge in self-insurance and HMO's. ${ }^{19}$ In all states, however, the Blue plans have by far the largest market share; no other single commercial insurer has a market share above 10 percent.

TABLE 2

\section{Blue Shield Market Shares, 1976 and 1980 and Physician Discounts, Selected Plans}

PIAAN

Massachusetts

Michigan

Florida

Pennsylvania

Maryland

California

New Jersey

New York (NYC)

Indiana

Virginia (Richmond)

Illinois (Chicago)

Ohio (Cleveland)

Kentucky

Iowa

Wisconsin (Milwaukee)

Alabama

Ohio (Worthington)

Tennesse (Chattanooga)

Summary:

Average Share, 1980,
Share 1976

59

60

34

69

51

19

53

48

46

41

28

65

41

54

34

41

39

34
Discount from UCR *

Share 1980

1980

28.2

27.5

25.8

20.1

18.3

17.8

12.9

11.3

10.5

10.1

9.9

9.6

8.9

4.0

3.0

2.9

1.9

1.0

Discount greater than $20 \%$ : 65

Discount 10-20\%: 42

Discount less than $10 \%$ : $\quad 39$

'Percent of total population with private health insurance.

"Usual, customary and reasonable fees.

Sources: Frech, Monopoly in Health Insurance, in Health Care in America 303 (H. Frech ed. 1988); Blue Cross \& Blue Shield Ass'ns, Fact Book (1977).

\section{B. Determinants of Blue Market Shares}

Analytic studies indicate three types of variables to explain cross-state variation in share. ${ }^{20}$ One set of variables refers to what might be called

19. Id.

20. All of these studies refer to the 1970's, and there has been no study that has tried to explain the changes over time in market share across areas. See Arnould \& Eisenstadt, The Effect of ProviderControlled Blue Shield Plans: Regulatory Options, in A New Approach to the Economics of Health Care 339, 341 (M. Olsen ed. 1981); Adamache \& Sloan, Competition Between Non-Profit and For-Profit 
"market niche," and the other set refers to regulatory and tax advantages available to the Blues in some states. The first set of variables is supposed to capture measures of disproportionally high demand for the type of insurance product-full coverage, service benefit, and free choice of providerproduced by the Blues. The other set of variables refers to the exemption from premium taxation and reserves requirements which is extended to the Blues in some states. There is a third set of influences sometimes discussed. These influences refer to provider boycotts and/or special price discounts offered by providers for the purpose of assisting a provider-dominated insurer. ${ }^{21}$

Empirical studies always find that market niche variables help to predict Blue market shares. For instance, Adamache and Sloan ${ }^{22}$ found urbanization and unionization to be positive influences, while Feldman and Greenberg ${ }^{23}$ found income to be a negative influence. ${ }^{24}$ Unions have historically preferred the "first dollar" coverage the Blues offer. High income might also be expected to lead to higher desired levels of coverage but it may also be that higher income consumers have less need of first dollar coverage. ${ }^{25}$ Although Adamache and Sloan do not give an explanation, the reason why urbanization would predict a high Blue share is presumably based on a correlation between urbanization and the type of employer who prefers Blue coverage.

States often impose excise taxes on insurance premiums, but the Blues often are exempt from those taxes. ${ }^{26}$ A premium tax advantage for the Blues, relative to commercial insurers, was found to be related to market share by Feldman and Greenberg for plans that also receive discounts on the price of medical care, but not for plans receiving no discounts. ${ }^{27}$ In contrast, Adamache and Sloan found no appreciable effect of tax advantages on either selling cost or market share for the full set of insurers. ${ }^{28}$ Arnould and Eisenstadt argue that a premium tax advantage combined with provider control leads only to higher provider prices, with no effect on market share. ${ }^{29}$ But the tax advantage will lead to higher market share, and lower provider prices, if the insurance plan is controlled by management that is independent of doctors or hospitals.

Health Insurers, 2 J. Health Econ. 225, 237 (1983); Feldman \& Greenberg, The Relationship between Blue Cross Market Share and the Blue Cross "Discount" on Hospital Charges, 48 J. Risk INs. 235, 240 (1981).

21. Arnould \&c Eisenstadt, supra note 20, at 341.

22. Adamache \& Sloan, supra note 20, at 237.

23. Feldman \& Greenberg, supra note 20, at 240.

24. Adamache and Sloan defined urbanization as "a proportion of Blue Cross area population in standard metropolitan statistical areas" and unionization as "proportional state non-agricultural work force unionized." Feldman and Greenberg have defined income as state per capita income. See generally Adamache \& Sloan, supra note 20; Feldman \& Greenberg, supra note 20.

25. Feldman \& Greenberg, supra note 20, at 239.

26. Congressional Research Service, A Primer on Health Insurance, in Health INSURANCE AND THE UNINSURED 15 (1988).

27. Feldman \& Greenberg, supra note 20, at 239.

28. Adamache \& Sloan, supra note 20, at 240, 242.

29. Arnould \& Eisenstadt, supra note 20, at 355. 
Still another potential influence on an insurer's share is whether it receives a discount from the posted price of the medical care it covers. As Table 2 shows, there is a strong relationship between discounts and share. But there is a critical problem in determining whether discounts affect shares: discounts surely are not exogenous and may themselves be causes of market power as well as influences on it. Economists have attempted to untangle those relationships, with mixed results. Frech and Ginsburg were the first to point out the positive relationship between discounts and market share. ${ }^{30}$ Feldman and Greenberg found that the existence of a hospital discount increases Blue Cross market share, but concluded that market share does not affect the chance of obtaining a discount. ${ }^{31}$ Adamache and Sloan, in partial contrast, found that Blue Cross market share does affect the size of the hospital discount $^{32}$ and that the discount affects market share. ${ }^{33}$

There is also likely to be an interaction between tax advantage and "niche" variables. If a Blue plan has some positive levels of tax advantages, and if it applies those advantages to yield a lower premium for the type of insurance in which it specializes, it will obviously have a large market share in that type of insurance. The larger the proportion of the population that prefers that type of insurance, the bigger its overall market share will be. If, in contrast, the Blue plan has no tax advantage over other insurers, it would not, without more, be expected to garner a very large share even in the type of insurance in which it specializes. Consequently, the market niche variables may also be expected to have stronger effects when the tax advantage is present. No one has tested this conjecture.

However, the power from tax advantages is limited. ${ }^{34}$ The exogenous sources of insurer market power other than governmental action (for example, tax subsidies) remain a mystery. Solving this mystery is important, because the "tax advantage" theory of market power has some serious problems as a rationale for (or against) antitrust concerns, especially federal antitrust concerns as applied to health insurance.

States have chosen to give premium tax advantages to Blue Cross and Blue Shield and to regulate them in ways that differ from the methods applied to other insurers. ${ }^{35}$ In so doing, a state would be presumed to be complying with federal antitrust requirements by acting in what it regards as the public

30. Frech \& Ginsburg, Competition Among Health Insurers, in Competition in the Health Care Sector: Past, Present, and Future 181 (W. Greenberg ed. 1978).

31. Feldman \& Greenberg, supra note 20, at 246.

32. Adamache \& Sloan, supra note 20, at 234.

33. Id. In all cases, the results are only as good as the exogenous variables that identify the relationships. For instance, in the Adamache and Sloan study, the only significant exogenous influence on the size of the discount was state rate-setting authority over the Blue Cross premium, which hardly seems like a source of market power. Feldman and Greenberg, supra note 20, at 238, use the percentage of a state's population with any insurance coverage as an exogenous variable, but one could argue that a Blue Cross discount would, by lowering price, increase that percentage, as well as Blue Cross' own market share.

34. See infra text accompanying note 45 .

35. See Congressional Research Service, supra note 26, at 15. 
interest and taking appropriate account of whatever monopolistic inefficiencies might arise from giving market advantages to the Blue plans. Indeed, the McCarran-Ferguson Act explicitly precludes the general application of federal antitrust laws to state regulated insurers, presuming that the state will guard against damaging exercise of market power. ${ }^{36}$ If states choose to offer advantages, how can the results of these legislative choices be challenged?

Perhaps more seriously, because the extent of market distortion is determined by the extent of market power, the level of distortion is limited by the size of the premium tax advantage. Suppose, for instance, that the source of market power is exemption of Blue Cross/Blue Shield from a typical 2 percent state premium tax that is imposed on other insurers. ${ }^{37}$ This advantage, as Frech and Ginsburg have noted, could allow Blue Cross/Blue Shield to obtain 100 percent of the market if it was as efficient as commercial insurers. $^{38}$ If, instead of having market share as its goal, a provider dominated insurer wanted to increase the profits of providers, it might set more generous maximum provider prices than would commercial insurers, prices in excess of some assumed competitive provider level. The critical point, however, is that the maximum advantage it could transfer to providers is 2 percent of total premiums-the level of the tax advantage. If it were to permit a price level for providers higher than that level, commercial insurers would be able to underprice its break-even premiums. It is in this sense that tax-based market power is limited.

How great a distortion would be implied by a 2 percent tax advantage? The answer, theory suggests, depends on the prevailing level of administrative expense, the elasticity of demand for insurance, and the supply conditions for insurance. Precise estimates are impossible at present, but the distortion is likely to be small relative to total health insurance premiums. It can, however, be larger relative to the administrative cost of insurance. ${ }^{39}$

Suppose, as Frech has suggested, that Blue Cross insurers adopt an all-ornothing strategy, choosing to offer only high coverage policies which stimulate demand for provider services. Here again, the buyer will buy such coverage only if he is no worse off then he would be if he purchased commercial insurance. This limits the distortion, the excessive coverage that a Blue plan can impose. If we conceptually define the distortion as the net money subsidy that the consumer must receive as an incentive to purchase the Blue policy, the distortion cannot exceed 2 percent of commercial insurance

36. 15 U.S.C. $\$ \$ 1011-1015$ (1983).

37. The federal corporate income tax exemption of the Blue plans has recently been reduced somewhat, but it is the state premium excise tax which is quantitatively much more important.

38. Frech \& Ginsburg, supra note 30 , at 170.

39. Suppose that the $2 \%$ premium tax advantage is $20 \%$ of a typical $10 \%$ group insurance administrative cost. Suppose also that the elasticity of demand for insurance is 0.5 . Then a rough estimate of the difference between the value of coverage and its cost would be $5 \%(0.5 \times 0.1)$ of total administrative cost. If, however, the Blues respond to the tax advantage not by increasing profit but by spending on wasteful administrative costs, the level of waste could be as great as the $2 \%$ tax advantage itself. That is nearly $20 \%$ of all insurer administrative cost, but $2 \%$ of total premiums. 
premiums. At conventional group insurance loadings of approximately 10 percent, a 2 percent advantage is significant relative to total administrative cost. ${ }^{40}$ But as a fraction of total benefits, the distortion is relatively small.

Few major sources of market power other than the tax subsidy have been identified, and even the influence of the tax subsidy is questioned by some studies. ${ }^{41}$ When populations are more likely to demand the type of coverage Blue Cross and Blue Shield offer, its market share tends to be higher. But what accounts for this high market share in the first place, and how can it be sustained? Put slightly differently, what advantage do the Blues have that cannot easily be copied by other insurers? Other insurers could (and do) offer the same kind of coverage, and should at least be able to duplicate what the Blues can offer. The investigation of this question will now be pursued in detail.

\section{IV}

\section{Competition IN THE MARKET For INDEMNity INSURANCE}

To analyze the joint product relationship, we first consider the prospects for competition among insurers in providing "pure" insurance. Such insurance may be defined as coverage that simply pools the risk of large medical expenses, and does not attempt any direct influence on the price, quality, or quantity of care. One way to represent such a market is to imagine that all insurance is restricted to the indemnity function. The insurance simply pays up to a fixed dollar amount, based on the evidence of medical expenditures. That is, the insurer-qua-insurer, simply finances the medical care cost.

This health insurer performs the four fundamental functions performed by any insurer:

(1) Selling;

(2) Collection of premiums;

(3) Verifying and paying claims; and

(4) Pooling risk.

Cost is always incurred for the first three functions. The pooling function is not itself necessarily resource-using. By the law of large numbers, if many independent risks are pooled, the risk that actual benefit payments per insured (and therefore actual profits per insured, given some premium) deviate from their average or expected value is miniscule. When individuals are risk-averse, the pooling of risk will increase their expected utility. This means that payments in excess of the expected value of losses could in principle be extracted from consumers However, if stockholders' risk is reduced by the law of large numbers, competition will prevent such consumers' surplus from being claimed by insurers. That is, if pooling

40. Frech \& Ginsburg, supra note 30 , at 170

41. Adamache \& Sloan, supra note 20, at 240. 
reduces risk, and if pooling itself is virtually costless, there will be no need to include a cost of pooling in the premium.

In a competitive market the price of insurance (best measured by the loading per dollar of benefits) must cover the first three costs. ${ }^{42}$ If the only risk was the riskiness of illness, and if the occurrence of illness is independent, then only those costs will need to be covered. ${ }^{43}$ However, the insurer must also forecast future fluctuations in health care costs; there may be some risk that is not "poolable." On the other hand, because premiums are collected in advance of benefit payments, there will be a modest return on those accruals. At least that portion of the insurer's risk portfolio that is correlated with systematic economy-wide risk will require a return on equity equal to the return on equity of similar risk elsewhere in the economy.

Monopoly power for a group indemnity insurer, of whatever source, is likely to be severely limited. The main limitation to such market power, for group insurance, is that the employer can bear the risk, leaving only the clerical functions to be contracted out. ${ }^{44}$ An employer of reasonable size can pool almost all of the risk himself, at zero cost, by self-insuring. Smaller employers can band together and self-insure. Any insurer that tries to charge more than necessary to cover clerical cost will find group customers turning to self-insurance.

Moreover, if a firm is owned by an individual with a diversified portfolio of assets, the firm should be willing to absorb some of the systematic risk. For example, the risk that medical care prices will rise at a different rate than expected cannot be reduced by pooling across individual buyers of insurance, since all are equally affected by prices. However, the impact of fluctuating medical care prices on profits received by the owner of the firm can be "diversified away" if the owner or owners also have a mix of other investments. Then when medical costs rise less rapidly than expected, some other input and output prices will fluctuate in the opposite direction, so that there will be little effect on the average return from investment portfolios. This means that the owner of a self-insured small firm that forms part of a diversified portfolio could, in principle, self-insure and pool medical price risk with the risks associated with his other investments.

Finally, entry into the insurance business per se is relatively easy, and the industry is relatively unconcentrated. States license insurance companies, but the number of insurers licensed to sell in a state is typically in the hundreds. There are relatively low minimum capital requirements and requirements to file individual premium rates (group rates are usually not subject to

42. The insurance premium will also include the cost of benefits to be paid, but this is not part of the cost of the insurance function per se.

43. A risk is independent if the probability that one person contracts an illness is not changed when another person gets an illness. Independence is not a reasonable assumption for contagious disease, but expenses for contagious disease treatment are relatively small.

44. About $32 \%$ of all workers are currently covered by self-insured and minimum premium plans. Many other plans are experience-rated, which can be closely analogous to self-insurance. See Arnett \& Trapnell, supra note 1, at 34. 
regulation). While no study of entry into health insurance has been conducted, Munch and Smallwood did find that stricter reserves requirements deterred entry by new small firms into property-casualty insurance. ${ }^{45}$ The deterrent effect does not apply, however, to already established firms seeking to enter new geographic areas, and the reserve requirements for health insurance are small in any case, since (in contrast to liability insurance) there is not a long lag between receipt of premiums and payment of benefits. In short, while entry is not completely free, barriers are so minimal that no appreciable amount of market power could be generated. And, as noted above, other than the Blues there is no insurer in any geographic market with a large market share. Literally hundreds of firms typically operate and, at least for the risk-pooling function, would be willing to accept large amounts of business.

The use of group experience rating reduces the need for actuarial data, and such data for standard populations are widely available anyway. Large nationwide insurers can easily set up the clerical facilities to enter separate localities. In short, other than in the area of tax subsidies, there is at present little scope for insurer market power in performance of the conventional indemnity functions, at least if consumers are knowledgeable.

However, not all consumers are knowledgeable about price or quality. The "quality" of insurance is an imprecise concept, especially for the indemnity function. The probability of default is largely governed by regulation of reserves, so that qualitative differences are limited to the efficiency of premium collection, the speed and accuracy of claims processing, and the attractiveness of the selling effort. Some consumer/buyers may be less than perfectly informed about quality and (especially) price, and this absence of information may in principle permit insurers to raise price appreciably above the competitive level. With group insurance the predominant form of sale, and with firm benefit managers the predominant buyers, it is unlikely that such gains could be large or permanent.

Consumer information imperfections could (and probably do) characterize the relatively small individual insurance market. Even here, reasonably free entry is probably sufficient to bid profits down to the competitive level, so that the main consequence of consumer ignorance for the risk-pooling function is not market power for any one insurer, but rather excessive selling costs and consumer misjudgment of the relative merits of different insurers. ${ }^{46}$

These comments are not the same thing as saying that no insurer will be able to garner a large share of the market. Even a small cost advantage to one insurer can permit that insurer to capture a large market share, especially if (as in the case of indemnity insurance) the product itself is undifferentiated. This situation occurs because buyers with no other reason to prefer an insurer

45. See generally Munch \& Smallwood, Solvency Regulation in the Properly-Liability Insurance Industry: Empirical Evidence, 11 BELL J. ECON. 261 (1980).

46. But see infra p. 267 (Part VII) for a discussion of the role of consumer ignorance and the cost containment function. 
than price will all select the insurer with the lowest price. But the ability to raise price above the competitive level will simply not exist. If the large share insurer should try to raise price, it will find multiple competitors who will match its price as soon as it uses up its cost advantage.

It is true that there may be some advantages to the health insurer who first offers a type of health insurance coverage. Until buyers can observe or get information about performance, they may prefer an insurer they know they can count on for benefit payments as compared to a new entrant. However, reserves and solvency regulation do largely guarantee benefit payments. In group insurance the failure to pay benefits in a timely fashion would quickly become apparent. Consequently, it is difficult to believe that there can be any important first entrant market power in performing indemnity insurance functions for groups. (There may be a modest amount of such market power in the individual insurance market, as will be discussed below.)

\section{V \\ INSURER-PROVIDER RELATIONSHIPS AND THE Expansion of Market Power}

\section{A. Forms of Monopsony Market Power}

A critical element in modelling competition is therefore the ability of an insurer to be more than just a financer of indemnities who leaves untouched the prices providers charge and the mix of services they provide; the insurer can become a buyer of services. ${ }^{47}$ That is, absent the ability to affect provider price, quantity, or quality, it would be very difficult for the health insurance market to be non-competitive, except temporarily or as the result of an explicit conspiracy or government regulation that strictly limits entry. And the possibility of self-insurance means that even such barriers would have limited effect on many employers and employees. In the sections that follow, this article will explore in more detail how the insurer's ability to have a direct effect on prices or quantities is the key to understanding competition in the health insurance industry.

Once one admits the possibility that insurance may affect the price or quantity of medical services in a way that differs from the effect of indemnity insurance as sold by competitive insurers, one has to consider a variety of possible objectives for insurers and a variety of possible strategies. Confusion arises in choosing appropriate theories and in interpreting evidence when the various possibilities are not distinguished. Table 3 provides a classification of models. The control over the insurer may either be held de facto by providers

47. The argument here is that, depending on the circumstances, the insurer can either function as financer or buyer. There is no direct economic rationale that prescribes one function over another. If the insurer does function as a financer, moral hazard means that insurance will affect the quantity of care demanded. If a larger quantity requires a higher price to be paid to suppliers, then price will also be affected. But the financer-insurer does not have any direct effect on price or quantity beyond these supply-demand effects, that is, beyond the effects that would have occurred had the quantity demanded increased for any other reason. 
organized collectively (hospitals in the case of Blue Cross; physicians in the case of Blue Shield), or by insurance management. Control obviously determines the objectives the insurer would pursue with any market power available. The tools for control to be discussed are: (1) effecting a uniform price charged to all patients; (2) causing a lower, discriminatory price for the insured's customers only (with the possibility that both the size of discount and the level of all prices will be affected); and (3) affecting the volume of services provided.

Indicated in the Table are some examples of past discussions of insurer market power that have focused on these six alternative cases. While the precise objectives of providers and insurers (especially when either or both are not-for-profit) are uncertain, we can provisionally assume that provider objectives are furthered, other things being equal, by higher overall provider price or benefit levels and/or larger quantities of medical services, while insurance management in contrast desires lower total benefits cost.

TABLE 3

\begin{tabular}{|c|c|c|c|}
\hline $\begin{array}{c}\text { FORM OF CONTROL/ } \\
\text { CONTROL }\end{array}$ & UNIFORM PRICE & $\begin{array}{c}\text { DISCRIMINATORY } \\
\text { PRICE }\end{array}$ & QUANTITY \\
\hline Provider & $\begin{array}{l}{ }^{1} \text { Oregon Phys. } \\
\text { Services }\end{array}$ & $\begin{array}{c}\text { Blue Cross } \\
\text { Discount } \\
\text { (traditional) }\end{array}$ & $\begin{array}{l}{ }^{3} \text { Frech- } \\
\text { Ginsburg } \\
\text { "Coverage } \\
\text { Forcing" }\end{array}$ \\
\hline $\begin{array}{l}\text { Insurance } \\
\text { Management }\end{array}$ & $\begin{array}{l}{ }^{+} \text {Lynk Theory of } \\
\text { Oregon Case }\end{array}$ & ${ }^{5}$ Ball Memorial $^{51}$ & $\begin{array}{c}{ }^{6} \text { Overly } \\
\text { Aggressive } \\
\text { Case } \\
\text { Management }\end{array}$ \\
\hline
\end{tabular}

The analysis will begin with the case in which discounting is not an issue; the insurer is simply trying to set price.

Oregon Physicians Services ${ }^{52}$ (Blue Shield), as interpreted by Goldberg and Greenberg, would qualify as an example of Cell 1:53 a providercontrolled, overall price-increasing plan. Oregon Physicians Services, the state physician-organized and controlled Blue Shield plan, was charged with attempting to set provider prices higher than other insurers (called "hospital associations") in the late 1930's, and to persuade physicians not to deal with the hospital associations. While the Supreme Court acquitted Oregon Physicians Services, Goldberg and Greenberg nevertheless support the view

48. United States v. Oregon State Medical Soc'y, 343 U.S. 326 (1952). (This Table refers to the conduct of Oregon Physicians Services, which is discussed in the cited case.)

49. Frech \& Ginsburg, supra note 30, at 173.

50. W. Lynk, The Ancestary of Physician-Sponsored Health Insurance (Health Econ. Resource Dept. working paper, Blue Cross Blue Shield Associations, June 1978).

51. Ball Memorial Hosp., Inc., v. Mutual Hosp. Ins., Inc. 784 F.2d 1325 (7th Cir. 1986), reh'g denied, 788 F.2d 1223 (7th Cir. 1986).

52. United States v. Oregon State Medical Soc'y, 343 U.S. 326 (1952).

53. See generally Goldberg \& Greenberg, The Emergence of Physician-Sponsored Health Insurance: $A$ Historical Perspective, in Competition in the Health Care Sector: Past, Present, and Future 288 (W. Greenberg ed. 1987). 
that the Blue Shield plan was a provider-dominated plan with market power. In contrast, Lynk alleged that the Oregon hospital associations were trying to hold down overall provider prices, as in Cell 4 , behaving in a monopsonistic way. ${ }^{54}$ Since there is no easy way to establish what the competitive price would have been, this issue is not resolved.

Cells 2 and 5 deal with prices that are set lower for the insurer's customers than for others. The provider-dominated insurer that, nevertheless, sets lower prices than its competitors features in more recent versions of the Blue Cross discount discussion (for example, Feldman and Greenberg), 55 although there is usually some ambiguity about the objectives of the insurer. A case in which the insurer is unequivocally alleged to have discriminatory overall price-depressing objectives is represented by the argument of the plaintiffs in Ball Memorial. ${ }^{56}$ Here the plaintiffs unsuccessfully argued that a Blue Crosssponsored preferred provider organization ("PPO") had compelled some hospitals to accept prices that were inappropriately low. ${ }^{57}$ Finally, Cells 3 and 6 describe another avenue for the vertical relationship between insurer and provider. Fears that HMO's or PPO's could be overly aggressive in utilization management have been expressed, as in Cell 6.58 In contrast, other articles have argued that provider-dominated insurers may cause overuse of medical services by forcing excessive levels of insurance coverage. ${ }^{59}$ If such a provider-dominated insurer possessed market power, it would not, as Frech and Ginsburg 60 have noted, be expected to try to maximize insurer profits, since higher insurer profits could well mean lower payments to providers. Nor could the insurer pay dividends to providers even if provider associations have nominal ownership. There are, however, two ways in which it can legally transfer rents to its provider-owners. One way has been described by Frech:61 By offering coverage that increases or at least does not limit the quantity of services demanded at any provider price, net incomes of providers will be enhanced. Another way to transfer rents is by setting benefit payments that result in prices that are higher than the competitive level. ${ }^{62}$ Either way, the net effect is to cause insurer premiums to be higher than the level under pure

54. W. LyNk, supra note 50, at 23.

55. Feldman \& Greenberg, supra note 20.

56. Ball Memorial Hosp., Inc. v. Mutual Hosp. Ins., Inc., 784 F.2d 1325, reh'g denied, 788 F.2d 1223 (7th Cir. 1986).

57. See Miller, supra note 15 , at $195,226-30$.

58. See generally Hillman, Financial Incentives for Physicians in HMOs: Is There a Conflict of Interest?, 317 New ENG. J. Med. 1743 (1987).

59. H. Frech, Market Power in Health Insurance: Effects on Insurance and Medical Markets, J. INDus. ECoN. 28, 59 (1979); see generally Frech \& Ginsburg, supra note 30.

60. See Frech \& Ginsburg, supra note 30, at 169.

61. See Frech, supra note 59 , at 56.

62. Typically service-benefits insurers, such as Blue Cross, do set actual prices paid to hospitals; as part of its Blue Cross contract, the hospital agrees to provide benefits in the form of services for this price, and not to bill patients for anything additional. In contrast, most Blue Shield plans set a maximum benefit level, with the physician permitted to bill for more than the benefit level. However, it is easy to see that the higher the benefit level, the higher the price the physician will be able to charge. 
indemnity insurance produced by an insurer with the same costs, and to cause provider net incomes likewise to exceed the level under indemnity insurance.

There are two ways of effecting this strategy. The most straightforward is for the insurer to set high provider benefits, and then set break-even insurance premiums high enough to cover the claims these benefit levels require. An alternative strategy, which Frech has proposed, is to offer only very high coverage policies, to refuse or discourage policies with deductibles and copayments, and to count on moral hazard from generous coverage to increase provider price, quantity, and incomes. ${ }^{63}$

While all of these cases are possible, the major point of this article is that the key to understanding insurer market power (if it is to exist) is as the result of discriminatory input pricing behavior. While market power is not ruled out in the non-discriminatory price or quantity-manipulation cases, it is much more limited.

Described below is a model that does lead to the conclusion that market power in excess of current tax or regulatory advantages is possible. This market power is exercised against providers; it represents monopsony rather than monopoly power. Also considered is an argument that investigates the possibility of transforming monopsony power into monopoly power in the form of higher prices charged to some buyers.

\section{B. Monopsony Power for the Management-Dominated Insurer}

This model makes the following assumptions:

1. One insurer initially has a large market share in the local market to be analyzed, while the other insurers' shares in the market are much smaller.

2. Each provider would be willing to accept a lower price rather than experience a substantial drop in volume from current levels. Explored below is a variety of conditions that can yield this motivation.

3. The initial provider price equals long-run marginal and average cost (that is, it is competitive). ${ }^{64}$

4. Each provider must, because of fixed costs and the geographically limited nature of medical services markets, serve customers of the dominant insurer as well as the customers of other insurers.

Given these four assumptions, the following strategy is pursued by a management-controlled dominant (large market share) insurer. It proposes to a provider that the provider accept a price from it that is less than the initial price. With regard to prices paid by other insurers, the provider may either be free to set whatever price it wishes for the fringe (small market share) insurers' customers, or the dominant insurer may require a specific price, higher than the price it is paying and possibly higher than the initial price, to be charged to those customers.

63. See Frech, supra note 59, at 59.

64. Long-run marginal cost means the change in total cost caused by varying output by one unit when all inputs are free to adjust. Long-run average cost is total cost divided by output. 
Will the provider accept this proposal? Staten, Dunkelberg, and Umbeck offer a basis for a negative answer. ${ }^{65}$ They allege that, rather than give a discount, providers would simply switch to other insurers and that all patients (buyers) will follow their current provider rather than stay with their current (dominant) insurer. The implicit threat to the provider rejecting the discount request is the potential departure of a sizeable chunk of its volume. However, if the provider does not expect the insurer to be able to "control" patients, there is no reason to give it a discount. The dominant insurer may be unable to withhold purchases because patients prefer a particular provider and because patients can and will switch insurers if the dominant insurer tries to switch them. The Staten, Dunkelberg, and Umbeck argument appears to state that if the insurance premium is the same for the dominant insurer and the alternatives, then providers will not believe that patients will follow the insurer's directions to avoid the recalcitrant provider. They say that, unless there is brand loyalty (which they believe to be unimportant), there is no reason for patients to be willing to follow insurer orders. ${ }^{66}$

The argument, in this form, appears to overlook an important step. The insurer expecting to extract a discount can set its premium at a level high enough to cover the discounted costs, below that of other insurers who must pay "full price." So even if there is absolutely no brand loyalty, the loyalty of any smart purchaser to the best price will be enough to make the insurer attractive and the threat to withdraw credible.

It is, however, possible to support the Staten, Dunkelberg, and Umbeck argument if one imagines that all providers collude and refuse discount requests. But such behavior, in addition to being unlikely, might raise antitrust problems of its own. Moreover, the only requirement for a threat to be credible is that enough buyers are willing to follow their insurer, not that all are willing to do so. ${ }^{67}$

As noted above, most insurance is offered in connection with employment. However, many employers now offer a PPO option, which carries lower premiums or better benefits in return for use of a particular subset of preferred providers. A few employers are furnishing only PPO or HMO coverage to their employees, ${ }^{68}$ thus strengthening the threat of the insurer to switch patients.

It is an initial large market share that will give a management-controlled dominant insurer a persuasive threat to providers. This large share can, through the process just described, be used to extract a discount, and then the discount can be used to support a premium lower than that which is

65. Staten, Dunkelberg \& Umbeck, Market Share and the Illusion of Market Power: Can Blue Cross Force Hospitals to Discount?, 6 J. HEALTh ECON. 43, 50 (1987).

66. Id. at 49 .

67. Pauly, Market Power, Monopsony, and Health Insurance Markets, 7 J. HEALTH Econ., 120 (1988); Pauly, Reply, 7 J. Health Econ. 85 (1985).

68. Kramon, Employers Test New Ways to Shift Risk on Health Costs, N.Y. Times, June 27, 1988, at 1, col. 1 . 
financially feasible for any other insurer. The lower premium in turn permits the large market share to be sustained.

The discount announced by a dominant insurer thus becomes a selffulfilling prophecy (which Frech has called a vicious circle). ${ }^{69}$ To begin this circle, only an initial large market share is required.

It is also possible to give an "entry barrier" interpretation to this strategic advantage. An entry barrier may be said to exist if a new entrant does not have access to the same demand-side and cost-side conditions as is true of existing firms. If an existing large insurer can obtain a critical input-medical service-at a lower price than a new firm, a barrier to entry may be said to exist. Even if a new firm has the same access to customers as existing firms, there is still a barrier if it has less favorable access to medical services. While capital is usually thought to be the input that new entrants have difficulty acquiring on equal terms with existing firms, that difficulty can in principle apply to other inputs as well.

This is obviously an oligopsony game, and there are probably some counter-strategies by the provider or providers that could defeat the dominant insurer. For instance, the provider could threaten to offer an even lower price to another insurer, thus causing the dominant insurer to lose its share of the provider's customers. On the other hand, the provider could attempt to conclude an agreement with other insurers that would yield volume sufficient to achieve minimum cost even without any dominant insurer business. Of critical empirical importance is the credibility of an insurer's threat to withdraw business, or to offer less attractive coverage (for example, indemnity coverage with a 20 percent copayment to non-participating providers), relative to the credibility of a provider's threat to deal entirely with non-dominant insurers. Here one may conjecture that a Blue Cross or Blue Shield threat to withdraw business or selectively reduce coverage would be taken seriously by many health care providers as long as the provider itself did not have a virtual monopoly in the market area; the option of entirely replacing those customers by insureds of other insurers would not be taken seriously. The strategy of contracting exclusively with other insurers is inhibited by the geographic nature of medical service markets and the presence of fixed costs.

This strategic explanation can be matched with Easterbrook's assertion about health insurance: that "[Health insurer] monopsony is inconceivable in most cases." 70 His argument is as follows:

[A]ny group of insurance companies that sought to curtail the use of medical care enough to depress [provider] prices would cause consumers to go elsewhere for insurance, and physicians would withdraw from the plan. Firms offering coverage sufficient to purchase the quantity of services patients desired would have an advantage in selling policies. Thus if the monopsony explanation prevailed, the insurers subscribing to the maximum price plan would lose market share, as happens when monopoly is at work. If the share of firms (buyers or sellers) participating in this

69. Frech, supra note 18 , at 301 .

70. Easterbrook, Maximum Price Fixing, 48 U. ChI. L. Rev. 886, 904 (1981). 
arrangement is increasing, this indicates efficiency-creating behavior rather than monopoly or monopsony. ${ }^{\text {, }}$

One immediate problem with this argument is that Easterbrook has the initial sequence of events backwards. The monopsonist does not "curtail use" to depress price, but rather depresses provider price first with the consequence of curtailing use as providers supply less care. ${ }^{72}$ But the more crucial point is the failure to notice that, if price can be successfully depressed by an insurer or set of insurers below what others are paying, the insurer could depress its premium and still cover costs. It is the lower premium, attractive to and providing benefits to buyers of insurance, that can sustain the differential insurer monopsony once it is achieved. This lower premium can more than offset the limitation on quantity (even the frustration of excess demand) that final consumers will experience in a monopsony insurance plan. Consumers will hate the limitation but console themselves by loving the low premium.

To be sure, an insurer with a smaller market share might likewise request a similar discount from a provider and threaten to take its small share elsewhere. At a minimum, the discount offered to such a firm would be lower, and the provider might, as a matter of strategy, more reasonably refuse such a request. In effect, the modest award of monopoly (insurance-selling) market power conveyed by such things as premium tax exemptions, if used to yield large market share, can be parlayed into possibly sizeable monopsony market power in purchasing inputs.

To sum up: A large market share, however acquired, provides a credible threat to an insurer dealing with an individual provider (doctor or hospital) as long as the provider would have even less profit if the threat were to be carried out than is represented by the discount request. The only way a provider could counter this strategy would be to locate another insurer who could replace the lost customers-whether by bringing them from elsewhere or by replacing the dominant insurer for its current set of customers. However, in most health care/health insurance markets there does not seem to be a candidate for this "white knight" role.

\section{Discounting and Provider-Dominated Insurers}

Up to this point it has been assumed that the discount is part of a strategy by a management-dominated insurer intended to reduce the payments to providers. In this section it is shown that a discount could even be an attractive strategy to a provider-dominated insurer. ${ }^{73}$ This explanation will at least help to resolve a paradox in the economic history of health insurance: why it was that even allegedly provider-dominated insurers imposed

71. Id.

72. The monopoly analogue is increasing provider price to curtail quantity demanded.

73. This argument parallels in many ways the explanation offered by Leffler, but does not invoke the HMO alternative which figures importantly in his discussion. Leffler argues that physiciandominated insurers require discounted prices in order to keep their premiums low enough to keep out the HMO alternatives. See Leffler, Arizona v. Maricopa County Medical Society: Maximum-Price Agreements in Markets with Insured Buyers, 2 Sup. CT. ECON. Rev. 187 (1983). 
discounts. ${ }^{74}$ In the words of a physician dealing with Oregon Blue Shield, "[j]ust why [Blue Shield] should have cut-rate fees (it was the original purpose in organizing the O.P.S.) in order to fight hospital associations, I cannot see ..."75

The critical notion is that the provider-dominated insurer will require a higher price to be charged to other insurers' customers as a condition of provider participation in its plan. It will therefore appear that the dominant insurer will be receiving a discount from the price charged to others. Forcing such a differential pricing arrangement will, as explained in the previous section, both be made possible by a large market share and permit that market share to be sustained. Moreover, such a pricing structure is consistent with an average price to providers that is above the competitive level.

The explanation is based on the same threat to withdraw business if a discount is not granted and maintained. Just as before, imagine that an insurer garners a large market share. The insurer then imposes a set of prices on the providers. This set might contain a price received from the dominant insurer that is higher than the competitive level, but a price to be charged to customers of other insurers which is higher still. At least the average price received would be higher than the competitive level. The dominant insurer price is nevertheless "discounted," and myopic providers might well complain that they would prefer the undiscounted price.

The threat against any provider who might set a lower (non-premium) price to other insurers is the threat to withdraw dominant insurer business. If that volume cannot easily be replaced, no individual provider will be willing to charge a price to other insurers which is not above the price received from the dominant insurer. This strategy forces any provider who wants to cut price closer to the competitive level in order to receive a large volume of business from another insurer to forego business from the dominant insurer. By the same argument as made above, many providers may find this sanction enough to give them fortitude to resist the usual competitive temptation to cut price back closer to marginal cost.

This is the difference between this case and the management-dominated one. Here the insurer will have to enforce discrimination by concentrating on the price charged to others, rather than only on the price charged to its insureds, and will have to threaten to withdraw participation if the price to others is cut.

The alternative strategy for the dominant insurer is to use the discounted price advantage to "force" more comprehensive conventional coverage on

74. It is, in contrast, easier to see why a provider-dominated insurer might try to control utilization directly. Having shifted the demand curve out with high coverage, it might well have overshot, and want to cut the quantity a little. Decades of Blue Cross ads on detailing costcontainment programs do not describe necessarily virtuous behavior but only the administrative controls required by generous coverage.

75. Goldberg \& Greenberg, supra note 53, at 242. 
consumers. $^{76}$ In effect, rather than just increasing profits on existing customers, the insurer induces more insureds to purchase comprehensive coverage. This strategy may be preferable to a wholly price-based strategy.

Furthermore, it is even possible that a discount from the initial (no insurer market power) equilibrium price can increase provider income if the initial price is above marginal cost for some other reason. For instance, suppose that physicians would, even in the most competitive practical market, be able to maintain a price somewhat above the competitive level. Discounting that price slightly, but using the discount to foster more comprehensive coverage, may actually increase provider net income.

\section{Other Considerations}

What of other reasons for a large market share? A state may give a tax subsidy to a Blue plan, recognizing that the subsidy will enhance its market share, as discussed above. But the tax subsidy advantage can be expanded into monopsony. It is more difficult to argue that the state intended to foster monopsony.

Perhaps the most interesting issue is that removal of tax or regulatory privileges will not be sufficient to eliminate monopsony, since the large market share continues to provide market power. A large share insurer can clone market power if it can engage in monopsonistic behavior.

A more difficult situation is set forth in the case in which an insurer obtains a large market share simply by being the initial entrant-by being there first with what turned out to be a good idea. Yet, success in the open market of new insurance products can generate monopsony. The appropriate remedies in this case are, in my opinion, less than obvious.

\section{E. What Might Market Power Mean in the Health Insurance Case?}

The burden of the argument for the management-dominated, discriminatory pricing case sketched out above is that it is possible that Blue Cross/Blue Shield plans can depress price below the pre-existing level. But how can such an action ever do damage? Is it not reasonable that, having declared there to be a problem of high health care costs, society should applaud the exercise of market power to force these costs down?

The first important point to note is that, in this monopsony case, market power means the ability of the insurer to force provider price profitably below the competitive level. This lower price means that, in contrast to the conventional antitrust case, monopsony does not necessarily reduce consumer welfare; it may even improve the well-being of consumers-quaconsumers, at least for some consumers. Like monopoly, monopsony reduces output below the level that maximizes the sum of consumer and producer

76. This is an adaptation of Frech's argument in which Blue Cross and Blue Shield were said to use market power to force more comprehensive coverage than buyers would have preferred. For an example, see Frech, supra note 18, at 293-322. 
surpluses. But unlike monopoly, monopsony does not achieve this result by pushing product price too high; it does so by pushing the price paid to suppliers too low. That is, monopsony operates on the supply curve rather than the demand curve; in so doing, it reduces supplier (not demander) welfare.

Confusion on this simple point is common. Easterbrook, for example, argues that:

[For insurance companies] to depress prices, they must curtail purchases; the purchase decision, however, is made by the insured patient, and once the patient has insurance, the marginal cost of health care is well below the price paid by the insurer. It is hardly possible to reduce the consumers' purchases of medical care by lowering the price they pay! ${ }^{77}$

But a moment's reflection will suggest that lowering prices paid to a set of suppliers will curtail purchases-not because doing so will reduce the quantity demanded (here Easterbrook is quite right), but because it will reduce the quantity supplied. After all, "purchases" in a market necessarily equal the quantity demanded or the quantity supplied, whichever is less.

In the case of monopoly, selling price can be pushed above the competitive level as long as the firm-level demand curve is not perfectly elastic. ${ }^{78}$ The analogous case for the supplier-provider is that the supply curve of the input medical services may not be horizontal; either providers do not produce at constant marginal cost or there is no supply curve because the provider market is not initially competitive.

If providers are assumed to be profit-maximizing, there are four possible ways in which a price reduction can be sustained:

(1) seller monopoly rents may be cut;

(2) quality may be reduced;

(3) quasi-rents may be cut; or

(4) producers' surplus to specialized inputs may be reduced.

The first case is one in which providers are initially charging prices above the break-even or competitive level, so that positive monopoly rents are being earned. In this case, the exercise of market power by insurers against providers represents bilateral bargaining; a buyer with market power is bargaining with a seller with market power. Buyer market power may be efficiency-improving if its exercise of market power stops when provider price has been pushed to the competitive level. Unfortunately, there is no particular reason why the buyer should stop at this point; the buyer can gain further monopsony advantages by pushing seller price below the competitive

77. See Easterbrook, supra note 70, at 904 .

78. A firm faces perfectly elastic demand if it imagines that it can sell as much as it wishes at the current price, but will sell nothing if it tries to charge more than the current market level. Such a firm is a "price taker." The demand curve is a horizontal line at a price equal to the current market price. By analogy, the insurer must imagine that, if it depresses the price it pays to providers slightly below the current level, at least some suppliers will continue to supply some care to its insureds. If depressing price causes a decrease in the quantity providers are willing to supply, but not an absolute decrease, the supply curve will have a positive slope. Broadly speaking, I will argue that the supply curve of care can have this configuration if not all sellers or providers of inputs do not produce at the same constant long-run marginal cost. 
level. ${ }^{79}$ Feldman and Greenberg take a benign view of insurer market power mobilized against prices that are too high. ${ }^{80}$ They apparently anticipate that the exercise of power will not be carried beyond the point at which prices are just high enough, but they offer no reason for this anticipation.

The quality-reduction case occurs when quality is variable and there is some competition among providers. Quality reduction can take many forms: less time per office visit, longer waiting time, fewer services per hospital stay, or less technically advanced services. There is a widespread belief among economists (if not among rhetoric-bound policy makers) that current medical quality or amenity may well be excessive, in the sense that hospitals provide overly intensive care, but there is no firm evidence on this point.

Quality may be excessive-carried to a level at which improvements in quality or amenity are worth less than their cost-because of insuranceinduced moral hazard. For example, a hospital may be willing to provide under-utilized high technology services because insurance covers the high price of those services, and because insured consumers have no reason not to patronize that hospital.

Since monopsony can push quality in the opposite direction, it could, up to a point, offset this distorted incentive. But, here again, there is no reason to expect the exercise of market power to stop at the ideal point; it might well lead to deficient quality, in the form of long waits, a slow rate of technical progress, and contrived shortages of useful care.

The third case is even more ambiguous. It is possible that current price just equals long-run marginal cost, but that some suppliers would for a time still be willing to render services even if price were cut because they have few short-run alternatives. Physicians, for example, might be receiving incomes just sufficient to yield the competitive rate of return on their investment in their education, and yet be receiving "quasi-rents," which are defined as incomes (and prices) in excess of the amounts needed to induce them to continue to supply their services in the short run. There are not many alternative uses for physician training; the sunk-cost nature of education (and of other kinds of specific capital investments) leads to quasi-rents. In such a case, price can be reduced and yet services will continue to be supplied as long as the price cuts only reduce quasi-rents and do not fall below short-run marginal cost. ${ }^{81}$ The casualty of a lower price is coverage of the cost of inputs, principally capital, fixed in the short run, but the short run in the case of medical human capital or hospital buildings can be very long indeed.

Finally, the last case is the classic monopsony case. Monopsony requires that inputs in the production of some good or service be specialized in the sense that their value in producing that service exceeds their value in other uses. It also requires that the specialized inputs differ in the minimum return

79. See Pauly, Reply, supra note 67 , at 119.

80. See generally Feldman \& Greenberg, supra note 20.

81. Short-run marginal cost refers to the change in total cost from varying output by one unit when only some inputs (such as human capital) are free to adjust. 
they require to furnish the service in question. Under competition the price paid to all sellers will be determined by the price required by the last, or marginal, seller; the other sellers will then earn "infra-marginal rents," in the sense that the price they receive exceeds the value of their input in the next best use.

Monopsony, which depresses the price paid to buyers below the competitive level, will reduce the infra-marginal rents to sellers. There are indeed specialized inputs to many health services. The implication then is that monopsony reduces the infra-marginal rents to suppliers of these inputs. That effect is only a transfer, however; the efficiency loss comes from restraining the use of critical inputs (and probably outputs) below the level at which the marginal willingness to pay of consumers equals the marginal willingness to be paid of suppliers of services.

As an example to illustrate this argument, consider the case of hospital services, broadly defined, and imagine that nurses provide specialized inputs to hospitals in a local market according to an upward-sloping supply curve. ${ }^{82}$ This supply curve reflects the alternatives different nurses have to hospital nursing in this local market. Now imagine that there is an additional amount of services nurses could provide (probably defined more as services per admission rather than as more admissions), but that supply of that increment would require that more nurses be hired. Imagine also that consumers would be willing to pay the opportunity cost of this increment; however, increasing the employment of nurses would drive up nurse wages. The problem is that the monopsony insurer will take account of the increase in wages to all nurses (and the increase in the price level of hospital services it would imply), and judge the improved intensity not to be worth that marginal factor cost. That is, the monopsony buyer recognizes that the higher wages must be paid not just to the newly hired nurses, but to all nurse employees. The marginal factor cost thus exceeds the wages paid to the newly added nurses. Both the insurer and consumers of insurance are better off not buying these additional services, since then they avoid paying the rents represented by higher wages to those nurses who were working at the initial wage level. There is a loss in welfare, but the loss is not to the marginal consumer. Instead, the loss falls on the marginal suppliers of nursing services.

This means that monopsony need not injure (or affect) competition in the final product market, that is, in the market for insurance. Monopsony does its welfare damage to competition in the input market-in markets for physicians' services, for hospital care, or for specialized inputs to hospital care, such as nursing. Antitrust's strong (though not exclusive) focus on

82. That is, more nurses can only be attracted to work at this hospital by increasing wages Some nurses, those tied to the local area or with a taste for nursing as a profession, would be willing to work for lower wages than others. That monopsony can be employed against nurses has been discussed by commentators on an earlier version of the nurse shortage, but the locus of monopsony behavior could well be transferred upstream to an insurer. See generally D. YETr, AN Economic Analysis of the Nurse Shortage (1975). 
competition in product markets has obscured a clear statement of how monopsony should be treated under antitrust law.

If the insurer can control the quantity of services directly, this is the end of the story. There is no moral hazard in the monopsony case, since the insurer can control care by manipulating the prices paid to suppliers of medical care. By holding the price paid to hospitals down, the level of service intensity is controlled, even though individual insureds may strenuously demand better nursing care. But the point is that they would not be willing to pay the premium for the insurance that sets a hospital price high enough to induce that greater level of intensity to be supplied. ${ }^{83}$

A similar argument to that applied to hospital care also applies to physician services. Individual physicians have upward sloping supply curves because of the increasing marginal disutility of work. Again, some services that would be efficient to supply will not in fact be made available if the insurer exercises full monopsony power. (Interestingly, even if the insurer was controlled by consumers, it would still behave as a full monopsonist if it acted in consumers' interest.)

Both the Blue Cross/Blue Shield insurers and the great majority of hospitals are not-for-profit firms. Theory and empirical evidence suggest that such firms will, nevertheless, frequently behave in the same way as for-profit firms, so the previous analysis will apply. ${ }^{84}$ But are there any differences that the not-for-profit form may cause?

The most frequently discussed answer to this question points to the possibility of cost-shifting-increasing the price to other customers of the provider when the dominant insurer compels a lower price. ${ }^{85}$ As noted elsewhere, the concept of cost-shifting rests on shaky theoretical ground if the

83. A monopsony health insurer could control moral hazard in an efficiency-improving way if it was motivated to do so. The mechanism, which to my knowledge has been overlooked in the discussion on moral hazard, is to set the provider price on the upward sloping supply curve of medical care services that brings forth just the quantity of services consumers would demand if they faced a price equal to marginal cost. See Pauly, Market Power, Monopsony, and Health Insurance Markets, supra note 67, at 119 for further discussion of this issue. There would still be excess demand, and a need to distribute the "optimal" total quantity optimally over individual demanders, but such a price-setting mechanism could well be an improvement. In addition, there might need to be nonprice rationing, or other forms of quality deterioration. But as long as this cost is not excessive, welfare may be improved. Id. Pauly shows that if the supply curve slopes upward, there is a price that can bring forth supply of the optimal total quantity of care, if one could determine beforehand what the optimal quantity is. The point of relevance here, however, is that one would not expect a profit-seeking monopsonist (or one run in the interest of consumers) to stop at this (second best) optimal point. Instead, the price would be pushed down to the monopsony equilibrium.

Note that the welfare-maximizing price would be one that prohibits balance-billing (just as does the monopsony price). Frech, supra note 18 , at 312 has cautioned that removal of out-of-pocket payments under a ban on balance-billing will stimulate spending, since consumers will surely demand more when care is free of user chargers. But there is a countervailing force: If providers are "on their supply curves," they will not be willing to supply the larger quantity buyers demand, and hence the higher expenses cannot become a reality. The worst that can happen (though it could be very bad indeed) would be the transaction cost associated with nonprice rationing of excess demand.

84. See generally Pauly, Nonprofit Firms in Medical Markets, 77 American Econ. Rev., 257 (1987).

85. See generally J. Meyer, W. Johnson \& S. Sullivan, Passing the Health Care Buck: Who Pays the Hidden Cost? (1983). 
enterprise is profit-maximizing. ${ }^{86}$ If, for example, the firm has constant marginal cost over the relevant range, and if that firm was initially charging the profit-maximizing price in the fringe market, it should not want to alter that price just because a discount was negotiated.

If, however, the firm was not-for-profit, it is possible that the initial price charged to others was below the profit-maximizing level, so that there will be an increase in that price following a discount to the dominant buyer. ${ }^{87}$ That is, faced with a constrained lower price in one market, the not-for-profit provider may push other prices up closer to the profit-maximizing level. If the provider itself has some market power, this can mean a price in excess of the competitive level for some customers.

A final issue concerns the behavior of not-for-profit insurers endowed with market power and cut loose from provider control. While the precise objectives of such firms are not known, a plausible story would have them setting both input and output prices as would a for-profit firm with the same market power, and then diverting some would-be profits to "dividends-inkind" received by management. If this happens, the potential efficiency consequences are, paradoxical as it may seem, much worse than if the firm maximized profits. The reason is this: In conventional monopoly/monopsony models, the profits of the firm are only transfers in welfare economics terms; it is the distortion of price signals which leads to welfare loss. This loss, while not trivial, is usually small relative to profits earned. But in the non-profit case, there is real potential that some of those profits will be wasted, in in-kind wages of management which are worth less than their cost. In effect, market power allows a firm with inefficient management-inefficiency in the form of an easy life or an edifice complex when it comes to headquarters buildings and real estate deals-to survive and prosper. Here again, it is only clear at present that these things are possible, but there surely is a threat that could be avoided if the market power were countered.

\section{F. Toward Measuring Monopsony Power by Market Share}

1. Introduction. An important insight into the conceptual framework thus far developed can be obtained by considering the relationship between market share, which is empirically observable, and monopsony market power, which is not. The classic empirically-based definition of seller (monopoly) market power has been provided by Lerner, who proposed a useful index to define, and ultimately measure, market power. ${ }^{88}$ An adaptation of the Lerner index to the monopsony case will highlight the critical elements in

86. See generally Pauly, Market Power, Monopsony, and Health Insurance Markets, supra note 67.

87. This point is discussed further by Foster, Cost Shiffing Under Cost Reimbursement and Prospective Payment, 4 J. Health Econ. 26I, 265-68 (1985), and Pauly, Market Power, Monopsony, and Health Insurance Markets, supra note 67, at 121.

88. See generally Lerner, The Concept of Monopoly and the Measurement of Monopoly Power, 1 REv. ECON. STUD. 157 (1934). 
determining the existence and size of monopsony market power in health insurance.

The model for the adaptation of the Lerner index to antitrust considerations is the Landes-Posner article, which clearly described the relevant influences needed to be considered in order to arrive at a judgment about market power. ${ }^{89}$ Landes and Posner dealt with the general monopoly case. Those concepts can be adapted to deal with the health insurance market.

2. Defining the Market. The Lerner index, as discussed by Landes and Posner, shows how a measure of market share can be modified into an indicator of market power. To apply this model to health insurance, the relevant market must be specified in order to define market share at the outset. The analysis will assume that the insurance market and the market for medical services are both local, in the sense of being limited to a single city. This is certainly a reasonable assumption for most medical services. For monopsony, however, it is the insurer's share in the market for medical services which is relevant.

3. The Lerner Index. The Lerner monopoly index measures the difference between the price the seller charges and the seller's (marginal) cost of output. ${ }^{90}$ The analogous monopsony index would equal the difference between the price paid for an input and its value to the firm. The latter quantity is simply the marginal revenue product of the input. ${ }^{91}$ This difference between price and value in turn is inversely related to the elasticity of supply of the input to the firm. For instance, if the input market is nearly perfectly competitive, the input supply elasticity will be high, and the deviation between input price paid and the value of output will correspondingly be low.

So the index of monopsony market power would equal $1 / e_{i}^{s}$ where $e_{i}^{s}$ is the elasticity of the supply curve to (buyer) firm $i$. If this elasticity is infinite, that is, if the buyer takes the input price as given, there can be no monopsony. Monopsony requires a less than perfectly elastic (and upward-sloped) supply curve, and that in turn requires some inputs specialized to the production of the good in question.

We can get some important insight into monopsony by expressing $e_{i}^{s}$ as:

$$
e_{i}^{s}=e_{m}^{s} / S_{i}+e_{j}^{d} \frac{\left(1-S_{i}\right)}{S_{i}}
$$

where $e_{m}^{s}$ is the market supply elasticity, $S_{i}$ is the firm's (buyer) market share, and $e_{j}^{d}$ is the demand elasticity for the input by the fringe insurance firms

89. See generally Landes \& Posner, supra note 9.

90. Lerner, supra note 88.

91. Marginal revenue product equals the additional output attributable to the input times the marginal revenue obtained from the sale of that output. 
(service purchasers). ${ }^{92}$ Market power, therefore, varies inversely with the market elasticity of supply and with the input demand elasticity of other firms, and directly with the firm's market share.

This means that if an insurer's market share is low, it will be unlikely to have monopsony power. But suppose an insurer's market share $S_{i}$ is relatively high. What then is the possibility that $e_{i}^{s}$ will nevertheless take on a high value; that is, that monopsony power will be low? One sufficient condition for this to happen would be a very high value for $e_{m}^{s}$ the market elasticity of supply. While one would not usually assume an infinite market elasticity of demand for any product, an infinite market elasticity of supply (horizontal supply curve) might well occur. One reason would be a situation in which the use of inputs for the particular product is only a small part of the larger total use of the inputs. For instance, a data processor buys computers in a large national market; there is no chance of monopsony there. The other possibility is that the local market can supply the service at roughly constant cost; this would occur if there are no specialized inputs and no industry-wide advantages or disadvantages of large scale production. Nursing home services, at least in the long run and without certificate-of-need restrictions, might be an example here. ${ }^{93}$

Conversely, market supply elasticity will be less than perfectly elastic if there is a limit on geographic transferability and there are specialized inputs into the services's production. Medical goods (drugs, appliances) would be geographically transferable, but most medical services would not. Services that use specially trained labor-physician services and hospital care-would surely qualify as services with non-infinite supply elasticities over any reasonable length of run.

The critical question concerns the other term in the index, the demand elasticity of the other insurers. If they are willing and able to buy all the medical services a provider wants to sell at prices just a little above what the dominant insurer is offering, then the latter firm would not possess market power. The question then turns out to be a simple one: Would a hospital or physician firm in a market in which the Blue plans have, say, a 50 percent market share believe that half of its business could be replaced by other insurers? If the answer is negative, then the conclusion is that the dominant insurer has at least some market power.

92. The equation says that the firm elasticity of supply is calculated as a weighted sum of the market elasticity of supply and the firm elasticity of demand for the other firms, with the weights being the market share of the dominant firm.

93. If the elasticity of supply to all buyers were high, one could say that all providers have sufficient capacity to accommodate any insurer-buyer. However, the other term, the demand elasticity by other insurers, is also important. There must be sufficient other insurer capacity to absorb the provider's output if the provider should lose dominant insurer business. 


\section{Demand Side Welfare Effects}

Thus far this article has emphasized the impact of dominant insurer market power on payments to suppliers and the consequent monopsony distortions. If this power is used to force the price other insurers must charge above cost, there also can be a reduction in the welfare of consumers who would otherwise have purchased that insurance. For such cost shifting to represent more than a transfer, there must be a difference, as far as some consumers are concerned, between the coverage furnished by the dominant insurer and that which would be supplied by other insurers; there must be qualitative differences among various insurance products.

To emphasize such differences, imagine that the dominant insurer offers only service benefit first dollar coverage, while at least some potential competitors might offer HMO-type coverage with lower premiums but more restrictions on use. Not all consumers prefer the HMO package to conventional coverage, but some do. In addition, imagine that the dominant insurer threatens to withdraw its business entirely from a provider if the provider contracts with an $\mathrm{HMO}$; in effect, the price imposed on the HMO competitor is infinite. (The argument also follows if the provider is required to charge the $\mathrm{HMO}$ a higher but less than infinite price.)

If there are no economies of scale in providing services, and no certificateof-need limitations, the consequent refusal of existing hospitals to deal with an HMO would not be an impediment. The HMO would simply hire its own providers and operate its own hospitals and would therefore still be able to obtain services at minimum cost. It seems reasonable, however, that such a strategy would not be feasible in most markets, given the small initial size of an HMO, the fixed costs associated with the construction of new hospital facilities, and the geographically limited nature of local medical care markets. ${ }^{94}$

If the HMO cannot incur equal costs and charge low prices, or is unable to offer coverage at all, those consumers who would have chosen the HMO will lose welfare, since they will be deprived of the chance of buying a type of service whose marginal opportunity cost they would have been willing to cover. The welfare loss is limited to the difference in utility between the HMO and the dominant insurer option, but such a difference will exist.

A similar argument applies to conventional insurers as well as to HMO's if they are willing to offer types of coverage and types of services that the dominant insurer is unable or unwilling to provide, but the price they must pay for inputs is forced above minimum cost.

If the dominant insurer also extracts a discount from marginal cost for its insureds, how does that discount affect welfare? If the discount is used by the

94. HMO's usually need to be able to deliver care soon after coverage is sold. The necessary lag in selling coverage to a large population means that an HMO's size when it initially starts delivering care will be small. 
dominant insurer to underprice (relative to cost) its more extensive coverage, there will paradoxically be a reduction in welfare even as purchasers of the insurance receive a subsidy. In effect, this privately engineered excise subsidy to the coverage offered by the dominant insurer causes more persons at the margin to choose that coverage even though it is worth less to them than its cost. In this sense, both the losers and the gainers in a discounting arrangement suffer a welfare loss; the loss for the gainers is masked by the transfer they receive, but it occurs nonetheless.

This reasoning might be applied to Reazin v. Blue Cross and Blue Shield of Kansas, Inc. ${ }^{95}$ If the "build your own hospital" option is ruled out, the action of the dominant insurer in effect reduces the welfare of the consumers who would have preferred the HMO. This would be so even if, from the dominant insurer's perspective, it was only adopting the sound business practice of negotiating a discount to fend off a new competitor.

\section{VII}

\section{Brand Loyalty and the Cost-Containment Function}

Consumers may have specific preferences toward the form of provider relationship an insurer obtains, and toward the effect that relationship has on both the circumstances of purchase of services and the level of benefits costs achieved. Virtually alone among private insurers, the Blue plans have provided service benefits, in which benefits are stated not in maximum dollar terms but in physical units. The Blue Cross plans especially cover "semiprivate accommodations," and other physically defined units of care in participating hospitals. Indeed, the long term special financial relationships Blue Cross has had with hospitals is a consequence of the service benefit definition.

While there is no evidence that this type of benefit and this type of relationship with hospitals necessarily leads to more consumer satisfaction than can be provided by commercial insurers with generous indemnity benefits, it is quite possible that the fifty-year relationship between Blue Cross and hospitals, and between Blue Shield and physicians, has produced a differential brand perception for the Blues, relative to any other health insurer. For some consumers, this differential perception may lead to brand loyalty. Can brand loyalty be a source of market power?

As noted above, benefits managers would be unlikely to have preferences for one insurer over another especially if the only insurance function were that of paying risk. But consumers who can choose among insurers may well attach some additional value to buying from the large market share insurer. This observation is perhaps more important today than it was a decade ago, because of the proliferation of multiple choice and flexible benefits options in group health insurance plans. In these arrangements, consumers have an

95. Reazin v. Blue Cross and Blue Shield of Kan., Inc., 663 F. Supp. 1360, 1420 (D. Kan. 1987). 
opportunity to choose from a menu of alternative insurers, HMO's, and PPO's.

The bases for Blue Cross/Blue Shield brand loyalty are not hard to find. The initial entrant into any business has some advantages. A large market share, even if caused by legislatively legitimate tax advantages, will generate a brand name recognition and a more efficient advertising strategy than is available to other firms. The vigorous protection of the Blue Cross trademark and the recent argument by Blue Cross plans for limitation on the use of this trademark both imply that the plans recognize this advantage. ${ }^{96}$

Speculation that advertising can confer market power, that there are first entry advantages, and that these features are reinforced by other special advantages to a seller are all fairly well-known economic propositions. Less clear, however, is whether this speculation, even if it is true, furnishes a basis for any legal action. Investment in advertising and good will is, at any point in time, open to any firm. If one firm has the foresight or the good fortune to enter first, and thereby finds that its advertising cost-effectiveness is higher than for subsequent entrants, the case for limitation of this advantage would be weak, and there might eventually be deterrent effects on innovation.

There is, however, another possible argument. If one accepts the view that, in their early years, Blue Cross/Blue Shield plans engaged in anticompetitive behavior, behavior which (among other things) made their market share higher than it would otherwise be, then one might be willing to accept that perhaps not all of their current good will is deserved.

The main problem with advancing this view is that of establishing the case that early market power did indeed exist. The case that dealt most directly with that question, United States v. Oregon State Medical Society, ${ }^{97}$ did result in acquittal of Blue Shield. Many commentators have, however, argued for the use of other interpretation of the evidence in that case. ${ }^{98}$ But in principle, a market share built on anticompetitive behavior, even if that behavior has by now ceased, should not be permitted to generate additional market power.

\section{VIII}

\section{CONCLUSION}

\section{A. Remedies for Insurer Market Power}

The large market shares reported earlier, and the relationship between market share, discounts, and tax and regulatory advantages for the Blue plans, all strongly suggest that the health insurance market does not work like a competitive market. There is presently no complete evidence on supply and

96. Central Benefits Mut. Ins. Co. v. Blue Cross and Blue Shield Ass'n, No. C-2-88-508, slip op. (D.C. Ohio Mar. 22 1989).

97. United States v. Oregon State Medical Soc'y, 343 U.S. 326 (1952).

98. Goldberg \& Greenberg, supra note 53; C. Havighurst, Testimony in U.S. Congress, Senate Subcomittee on Antrtrust and Monopoly of the Judiciary, Hearings: Competition in the Health Services Market, 93rd Cong., 2d Sess. 1024 (1974). 
demand elasticities discussed above, so one cannot be fully conclusive here, but the evidence is powerfully suggestive.

The difference from a competitive equilibrium, I hasten to add, is not likely to be apparent in the degree of perceived rivalry at the margin between the Blues and other insurers. The Blues will correctly perceive that they are in a daily struggle for market share and for profitable business, given the discount they have negotiated and the mix of policies they have chosen to offer. Shifts in consumer tastes for types of policies and the availability of other alternatives will mean (and has meant) that the Blues will lose business and will have to work hard to maintain what they have. But the evidence does seem to indicate that there is a core of advantage made available to the Blue plans in many (although not all) geographic areas, and that this advantage results in market equilibrium different from what it would have been had the Blues never been given those advantages.

As usual, both public policy and the law are charged with making educated guesses about what steps might improve welfare. There is no evidence that demonstrates that the Blues are more efficient in producing insurance (the financing function) than are their commercial rivals. And the territorial restrictions that the Blues impose on themselves prevent those plans that could achieve economies of scale from doing so. (The presence of viable small firms in the commercial markets suggests that the existence of economies of scale in health insurance is not a foregone conclusion.)

The well-advertised activity of the Blues in forcing cost control on providers is, as noted above, what we would expect, given their generous benefit plans. It is also subject to monopsonistic abuse and, in any event, its effectiveness has never been convincingly documented.

Removal of the tax subsidies would be a potential remedy for possible market power, and Congress has already taken a small step in that direction with regard to federal taxation. ${ }^{99}$ The argument made above implies, however, that removing the subsidy alone and leaving the large market share it caused in place will not be sufficient to prevent the exercise of market power. Attempts to enhance a plan's discount-enforcing power (as in bans on balance-billing) or to exercise that power (as in a Blue-sponsored PPO) should still be viewed with caution.

\section{B. From Theory Back to Reality}

The source of insurer market power that this article has emphasized is a market-share-based discount, and it has been argued that this source can generate market power regardless of whether the dominant insurer is controlled by providers or by its management (or its customers). For the numerous examples of hospital discounts, and for the less frequent examples of balance-billing-bans for physician services, this argument applies. Brand loyalty provides another explanation for market power, but one less obviously

99. Tax Reform Act of 1986, 98 Stat. 494, Stat. No. 5-1082. 
a candidate for legal limitation. But there are some Blue Cross plans that never required discounts, and many Blue Shield plans historically have not done so. Are these non-discounting plans only subject to the weaker brand loyalty criticism?

To an extent, the answer is that some Blue plans are free of all antitrustrelated criticism. In general, those Blue Cross plans with no discounts have low market shares, and therefore are not a matter of concern. ${ }^{100}$ However, there are instructive exceptions. Until recently, for example, Indiana Blue Cross received no discount and had a market share of about one-third. ${ }^{101}$ But Indiana Blue Cross did operate a quasi-public hospital rate-setting program, one which effectively defused many competitive strategies that might otherwise have been available to other insurers, by in effect operating a pricefixing mechanism. So in some few cases, large market share Blue Cross plans have selected substitutes for discounts.

That still leaves the non-discounting Blue Shield plans. It is only fair to admit that we are still continuing the search begun in Oregon State Medical Society ${ }^{102}$ for the smoking gun. Perhaps some source of market power (in excess of state-awarded advantages) can be found, but as of yet none has been discovered. However, should such plans turn to discrimination (in the form of balance-billing bans, maximum-price agreements, or straightforward discounting-bidding requirements), then the arguments given above would apply.

\section{Concluding Summary}

The possibilities for competition among health insurers and the need for antitrust scrutiny depend upon which function health insurers are performing. If they are limited to being arm's-length poolers of risk and financers of medical bills, there is little reason to anticipate the development of market power; the market will be competitive. Especially favorable tax or regulatory treatment may produce large market shares for the "Blue" insurers, and the large share insurers probably will use the cost advantages they have been given, but market power cannot be pushed beyond this legislatively bestowed (and approved) level. For large group purchasers, the ease of entry and expansion by existing firms, and the self-insurance option, are probably sufficient to ensure that price will not rise above the level needed to cover administrative costs.

There are, however, two alternative sources of market power that may be subjects of concern. For individual and small group insurance purchasers, advertising and brand name effects may lead to an ability to raise price above marginal cost. However, the antitrust interpretation of this source of market power is unclear. The second source is the potential ability of an insurer

100. See Table 2, supra p. 243.

101. Staten, Dunkelberg \& Umbeck, supra note 45, at 52; Pauly, Market Power and Health Insurance: Thinking Straight While Standing on Your Head, 6 J. Health Econ. 77 (1987).

102. United States v. Oregon State Medical Soc'y, 343 U.S. 326 (1952). 
which is a large market share purchaser of medical care inputs to exercise monopsony power in the inputs markets. Such monopsony can lead to greater market power in the sale of health insurance, but it also has important anticompetitive distortions of its own in markets for medical services. The cost of these distortions falls primarily on suppliers of inputs-but doctors and nurses are people whose welfare ought to count. The Lerner index shows that a large market share can lead to monopsony if there are specialized inputs in production (or substantial earmarked capital investments) and other insurers are not expected by buyers to be able to replace dominant insurer business whose withdrawal is threatened. ${ }^{103}$

Not only does monopsony permit politically legitimate advantages to be extended to more market power than was intended; it also permits market power to survive even after the bases for a large initial market share-whether tax subsidy, first entry, special relationships with providers, or brand loyaltycease to exist.

Monopsony is uncommon as a source of permanent market power because there are few services (and even fewer goods) that combine a large buyer market share and inputs highly specialized in the production of a particular output. Physical capital, once investment is actually made, can be productspecific, but its useful life is often relatively short. Perhaps it is the importance of human capital-professional training-which is less malleable, less adaptable, and less moveable, that raises a greater danger of monopsony in medical markets. The possibility of an insurers-consumer cartel against providers, even one with serious inefficiency consequences, also makes analysis more difficult and policy remedies less attractive on the surface. The efficiency consequences of this market power are long term, but no less important for that reason.

103. Lerner, supra note 88 . 
. 